\title{
Precipitation extremes in the wettest Mediterranean region (Krivošije) and associated atmospheric circulation types
}

\author{
V. Ducié ${ }^{1}$, J. Luković ${ }^{1}$, D. Burić ${ }^{2}$, G. Stanojević ${ }^{3}$, and S. Mustafić ${ }^{1}$ \\ ${ }^{1}$ University of Belgrade, Faculty of Geography, Belgrade, Serbia \\ ${ }^{2}$ Hydrometeorological Service of Montenegro, Podgorica, Montenegro \\ ${ }^{3}$ Geographic Institute "Jovan Cvijič" of the Serbian Academy of Sciences and Arts, Belgrade, Serbia
}

Correspondence to: V. Ducić (vladan@gef.bg.ac.rs)

Received: 5 May 2010 - Revised: 15 August 2011 - Accepted: 12 February 2012 - Published: 22 March 2012

\begin{abstract}
The aim of this paper is to analyse indices of extreme precipitation in Krivošije, Montenegro, the wettest Mediterranean region, from the period 1951-2007 and their relationships with atmospheric circulation using "SynopVis Grosswetterlagen" (SVG) series. Data from two stations were analysed, namely Crkvice $\left(42^{\circ} 34^{\prime} \mathrm{N}\right.$ and $\left.18^{\circ} 39^{\prime} \mathrm{E}\right)$ and Herceg Novi $\left(42^{\circ} 27^{\prime} \mathrm{N}\right.$ and $\left.18^{\circ} 31^{\prime} \mathrm{E}\right)$. Four indices of precipitation extremes (SDII, R75p, R95p, R95pTOT) were assessed including number of dry days. The results suggest that the number of days with precipitation decreased. To analyse the relationship between extreme precipitation events and circulation types we have used an efficiency coefficient $\left(E_{\mathrm{c}}\right)$. Regarding relation to atmospheric circulation, westerly, southwesterly and northwesterly circulation types with anticyclonic features over Central Europe are more frequent for dry days (days with $R<1.0 \mathrm{~mm}$ ) and northerly, easterly and southerly types for wet and very wet days (R75p and R95p indices). The types with cyclonic condition over Central Europe show a large proportion of wet and very wet days. Also, activity of Genoa cyclogenesis and orographic influence over a small area are the main reasons for the high precipitation amounts recorded in the Krivošije region (Crkvice).
\end{abstract}

\section{Introduction}

There has been considerable interest in the study of precipitation and temperature extremes (Klein Tank and Können, 2003; Zhang, 2000, 2005, 2009; Moberg et al., 2006; Zolina, 2008; Durao et al., 2010; Ceasar et al., 2011) because of their great impact on the environment and society. Precipitation extremes, in particular, often have major impacts on soil erosion that can result in soil degradation. This risk is especially present in the Mediterranean region, where agricultural ar- eas are sparsely distributed. To set up appropriate land use management strategies, it is important to estimate changes in the frequency and the intensity of precipitation extremes over time. Such estimates are even more important in the wettest Mediterranean areas (such as Krivošije, Montenegro) where heavy rainfall may have serious implications.

Extreme precipitation events have been analysed for different Mediterranean countries and weather stations (Gonzalez-Hidalgo et al., 2001; Goodess and Jones, 2002; Brunet et al., 2007; Durao et al., 2009; Kioutsioukis et al., 2010; Toreti et al., 2010). Tolika et al. (2007) analysed extreme precipitation conditions over the Eastern Mediterranean and their association with circulation types.

In their analyses of climate variability for the eastern region of the Mediterranean, Kostopoulou and Jones (2007a, b) found signifcant increases in the anticyclonic circulation types for the winter season. They found statistically signifcant negative trends for many cyclonic types in all seasons, especially for those types associated with activity of depression in the central region of the Mediterranean during the period 1958-2000. They also suggest that anticyclonic circulation types lead to dry conditions, while cyclonic circulation brings southern maritime airflows into an area and is thus associated with increases in rainfall.

Dünkeloh and Jacobeit (2003) investigated circulationrainfall relationships for the whole Mediterranean area and for all seasonally different types of coupled variability. Trends towards drier conditions in large parts of the Mediterranean region have also been observed. Sousa et al. (2011) investigated patterns and extremes of drought indices in the 20th century in the Mediterranean region and found a clear trend towards drier conditions in most western and central Mediterranean regions. Exceptions were northwestern Iberia and most of Turkey; these areas showed an increase in moisture availability. 
Table 1. List of stations.

\begin{tabular}{lllllll}
\hline Country & Station name & WMO & Period & Latitude (N) & Longitude (E) & Elevation (m) \\
\hline \multirow{2}{*}{ Montenegro } & Crkvice & - & $1951-2007$ & $42^{\circ} 34^{\prime}$ & $18^{\circ} 39^{\prime}$ & 937 \\
& Herceg Novi & 13455 & $1951-2007$ & $42^{\circ} 27^{\prime}$ & $18^{\circ} 31^{\prime}$ & 40 \\
\hline
\end{tabular}

Table 2. Definitions and abbreviations of the ETCCDI indices of precipitation extremes used in this study.

\begin{tabular}{lll}
\hline Index & Definition & Units \\
\hline SDII & $\begin{array}{l}\text { Simple Daily Precipitation Intensity Index (Annual to- } \\
\text { tal/Number of days with precipitation } \geq 1 \mathrm{~mm} \mathrm{day}^{-1} \text { ) }\end{array}$ & mm day $^{-1}$ \\
\hline R75p & $\begin{array}{l}\text { Number of days with precipitation amount above a site } \\
\text { specific threshold value for moderate days, calculated as } \\
\text { the 75th (R75\%) percentile of the distribution of daily } \\
\text { precipitation amounts at days with } R_{\mathrm{d}} \geq 1 \mathrm{~mm} \text { in the }\end{array}$ & Days \\
& 1961-1990 baseline period. & \\
\hline R95p & $\begin{array}{l}\text { Number of days with precipitation amount above a site } \\
\text { specific threshold value for very wet days, calculated } \\
\text { as the 95th (R95 \%) percentile of the distribution of } \\
\text { daily precipitation mounts at days with } R_{\mathrm{d}} \geq 1 \text { mm in } \\
\text { the 1961-1990 baseline period }\end{array}$ & \\
\hline R95pTOT & $\begin{array}{l}\text { Fraction of annual total precipitation due to events } \\
\text { exceeding the 1961-1990 95th percentile }\end{array}$ & $\%$ \\
\hline
\end{tabular}

Definitions including formulas are available from ETCCDI website http://cccma.seos.uvic.ca/ETCCDI/.

In contrast, analyses of six daily rainfall categories for 265 stations in Mediterranean Spain, Italy, Cyprus and Israel for the period 1951-1995 have shown increases in extreme daily rainfall in spite of the fact that total rainfall has generally decreased. This pattern is explained by an increase in the frequency and persistence of sub-tropical anticyclones, particularly over the Mediterranean (Alpert et al., 2002).

Unkašević et al. (2004) studied annual precipitation variability over Serbia and Montenegro. They examined the dependence of three selected absolute measures of variability of mean annual precipitation (standard deviation, absolute mean deviation and mean absolute interannual variability). In addition, two cases of extreme precipitation in Serbia were analysed using the gamma probability density function. Their results show no significant changes for either case of extreme precipitation.

The region of Krivošije is poorly documented in terms of precipitation extreme analysis and their relationships with atmospheric circulation types even though it is Medeterranean precipitation extreme. This highlights intersts for our study which is the first one over the investigated area.

The aims of this paper are (a) to create a statistical analysis of indices of precipitation extremes in the wettest place in the Mediterranean region and (b) analysis of the relationship between these indices of precipitation extremes and "SynopVis Grosswetterlagen" (SVG) series circulation types for European land areas.

\section{Data and methodology}

In this paper, daily and annual precipitation time series from the neighbouring meteorological stations Crkvice and Herceg Novi were used. Both of the stations are located in the southwestern part of Montenegro (Fig. 1). Daily precipitation data were obtained from the Hydrological and Meteorological Service of Montenegro. The Crkvice meteorological station (Table 1) is located in the Krivošije region on the southeastern slope of Orijen Mountain. It presents the highest average annual precipitation extreme found in $\mathrm{Eu}-$ rope (http://www.ncdc.noaa.gov/oa/climate/globalextremes. html). The high annual precipitation is mostly due to orographic uplift (Radovanović et al., 2008). It is located in a rural settlement with 76 inhabitants (census 2002) and in an area of typical Mediterranean karst, with little surface water and an abundance of groundwater. The average annual precipitation during the 1961-1990 baseline period was $4593 \mathrm{~mm}$, with the wettest season being winter $(1703 \mathrm{~mm})$. 


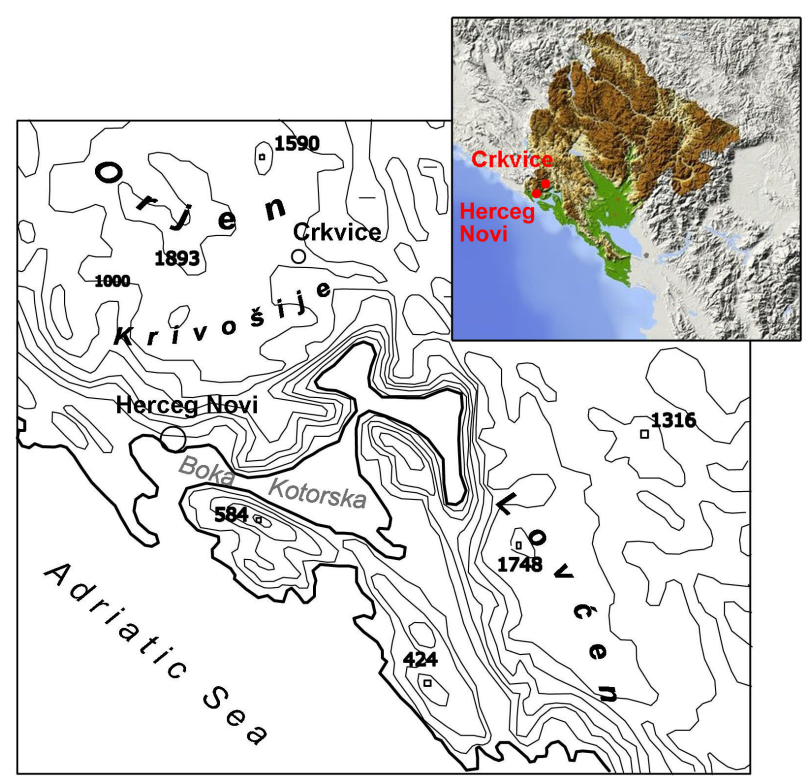

Fig. 1. Location map.

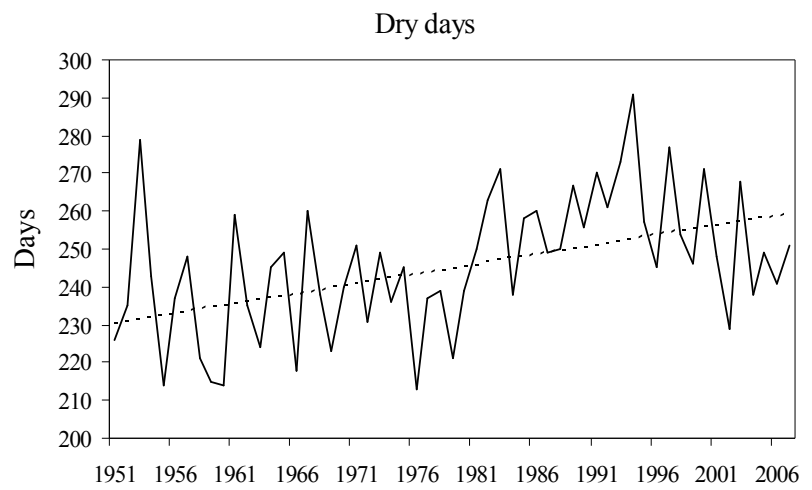

Fig. 2. Number of dry days for the Crkvice station for the period 1951-2007. Dashed line indicates Sen's estimator of the slope.

The second station used in this paper is Herceg Novi (Table 1), which is located in Boka Kotorska bay in the lower part of the Krivošije region and at the base of the southern slopes of Orijen Mountain. It is situated in a small tourist resort with 3754 people (census 2002). The average annual precipitation during the 1961-1990 baseline period was $1922 \mathrm{~mm}$ and the maximum was during the winter $(662 \mathrm{~mm})$. These two stations were selected because Crkvice is the wettest place in the Mediterranean and Herceg Novi has a complete data series. There is another rain gauge station at Vrbanja located in the Krivošije region; however, we did not include this station because more than $50 \%$ of the data were missing.

Daily precipitation time series used for the analysis cover the period from 1951 until 2007. Although data qual-

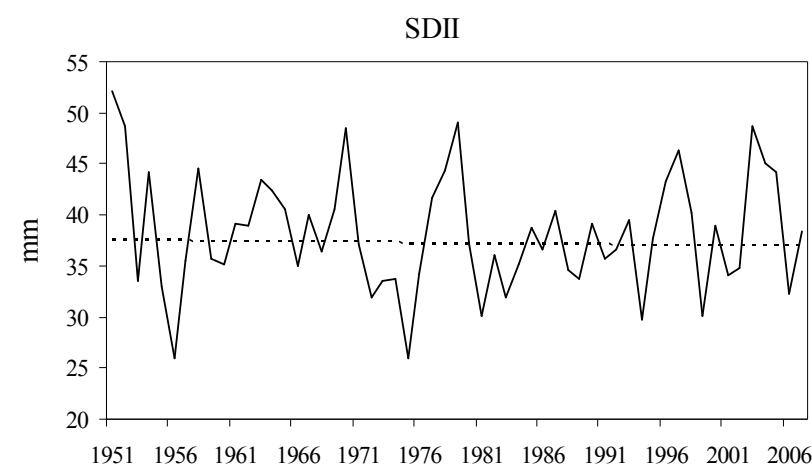

Fig. 3. Average daily precipitation intensity per day with precipitation (SDII) for the Crkvice station for the period 1951-2007. Dashed line indicates Sen's estimator of the slope.

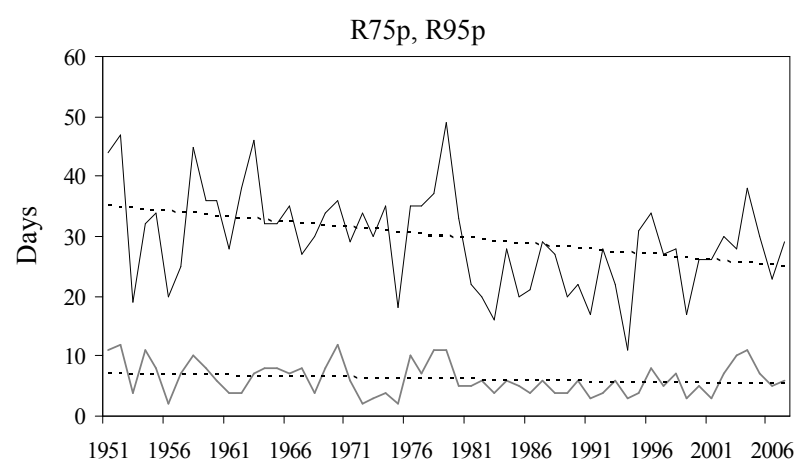

Fig. 4. Number of days with $R_{\mathrm{d}}>75$ th (R75p in black) and $R_{\mathrm{d}}>$ 95th (R95p in gray) percentile for the Crkvice station for the period 1951-2007. Dashed line indicates Sen's estimator of the slope.

ity control was provided by the Hydrological and Meteorological Service of Montenegro, data were additionally quality controlled following the standards recommended by WMO (2002). Metadata for the stations were considered in terms of relocation or mal-operation at the station. There were missing data for the Crkvice station (8.12\%); they were calculated using the complete series from the Herceg Novi station. Misprints are also identified and corrected.

In assessing changes in precipitation extremes or analysing climate variability, time series homogenity is a basic requirement. Unfortunately, an advanced correction method for daily precipitation time series is not developed yet (Toreti et al., 2010). In this paper data were first visually examined and compared with those from neighbouring stations. The data are also carefully evaluated applying a Multiple Analysis of Series for Homogenization (MASH) method. The MASH method was developed in the Hungarian Meteorological Service (Szentimrey, 1994, 1999, 2003); it is a relative homogeneity test that does not presume that the reference series are homogeneous (Costa and Soares, 2009). In this study a version MASHv3.02 extended for 
Table 3. GWT and GWL with definitions (Gerstengarbe, Werner, 2005).

\begin{tabular}{|c|c|c|}
\hline GWT & GWL & Definition of GWL \\
\hline & $01 \mathrm{WA}$ & West nticyclonic \\
\hline \multirow[t]{3}{*}{ West (W) } & $02 \mathrm{WZ}$ & West cyclonic \\
\hline & $03 \mathrm{WS}$ & Southern West \\
\hline & $04 \mathrm{WW}$ & West angular \\
\hline \multirow{2}{*}{ Southwest (SW) } & 05 SWA & Southwest anticyclonic \\
\hline & $06 \mathrm{SWZ}$ & Southwest cyclonic \\
\hline \multirow{2}{*}{ Northwest (NW) } & 07 NWA & Northwest anticyclonic \\
\hline & $08 \mathrm{NWZ}$ & Northwest cyclonic \\
\hline \multirow{2}{*}{ Cen. Euro. High (HM) } & $09 \mathrm{HM}$ & Central European high \\
\hline & $10 \mathrm{BM}$ & Central European ridge \\
\hline Cen. Euro. Low (TM) & $11 \mathrm{TM}$ & Central European low \\
\hline \multirow{6}{*}{ North $(\mathrm{N})$} & $12 \mathrm{NA}$ & North anticyclonic \\
\hline & $13 \mathrm{NZ}$ & North cyclonic \\
\hline & 14 HNA & North, Iceland high, anticyclonic \\
\hline & $15 \mathrm{HNZ}$ & North, Iceland high, cyclonic \\
\hline & $16 \mathrm{HB}$ & British Isles high \\
\hline & 17 TRM & Central European trough \\
\hline \multirow{2}{*}{ Northeast (NE) } & 18 NEA & Northeast anticyclonic \\
\hline & 19 NEZ & Northeast cyclonic \\
\hline \multirow{4}{*}{ East (E) } & $20 \mathrm{HFA}$ & Fennoscandian high anticyclonic \\
\hline & $21 \mathrm{HFZ}$ & Fennoscandian high cyclonic \\
\hline & $22 \mathrm{HNFA}$ & Norwegian Sea/Fennoscandian high anticyclonic \\
\hline & $23 \mathrm{HFNZ}$ & Norwegian Sea/ Fennoscandian high cyclonic \\
\hline \multirow{2}{*}{ Southeast (SE) } & 24 SEA & Southeast anticyclonic \\
\hline & $25 \mathrm{SEZ}$ & Southeast cyclonic \\
\hline \multirow{5}{*}{ South (S) } & $26 \mathrm{SA}$ & South anticyclonic \\
\hline & $27 \mathrm{SZ}$ & South cyclonic \\
\hline & $28 \mathrm{~TB}$ & British Isles low \\
\hline & 29 TRW & Western Europe trough \\
\hline & $\mathrm{Ue}$ & Transitional days \\
\hline
\end{tabular}

Table 4. Trend analysis of number of dry days for the Crkvice and Herceg Novi station (with statistical significance values) .

\begin{tabular}{lll}
\hline Station & Threshold & Mann-Kendall test value \\
\hline Crkvice & $R_{\mathrm{d}}<1 \mathrm{~mm}$ & $3.59^{* * *}$ \\
\hline Herceg Novi & $\mathrm{Rd}<1 \mathrm{~mm}$ & $2.97^{* *}$ \\
\hline
\end{tabular}

*** Significant at $0.1 \%$ level.

** Significant at $1 \%$ level.

homogenization of daily precipitation data has been applied. Portions of time series with inhomogeneities were excluded from the analysis.
Expert Team on Climate Change Detection and Indices (ETCCDI), which is supported by World Meteorological Organization (WMO) Commision for Climatology, the Joint Commision for Oceanography and Marine Meteorology (JCOMM) and the Research Programme on Climate Variability and Predictability (CLIVAR), developed a list of temperature and precipitation indices. In this paper we selected a set of four indices of precipitation extremes (Table 2). The chosen precipitation indices describe four wet extremes (R75p, R95p, SDII and R95pTOT). The indices are defined in terms of numbers of days that exceed either absolute or percentile thresholds. The index R95pTOT is the fraction of annual precipitation that is due to very wet days. It was chosen to explore the supposedly amplified response of 


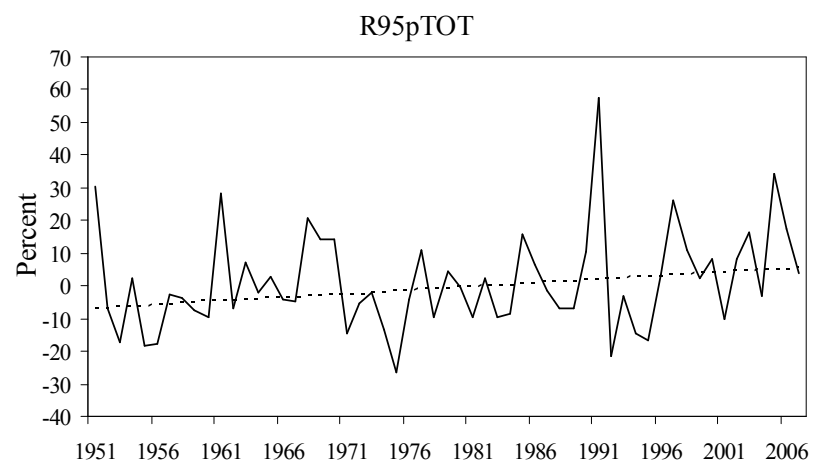

Fig. 5. Fraction of precipitation amount due to very wet days (R95pTOT) for the Crkvice station for the period 1951-2007. Dashed line indicates Sen's estimator of the slope.

Table 5. Trend analysis of precipitation extremes (with statistical significance values) for the Crkvice and Herceg Novi station.

\begin{tabular}{llll}
\hline Station & Index & Threshold & $\begin{array}{l}\text { Mann-Kendall } \\
\text { test value }\end{array}$ \\
\hline Crkvice & SDII & & -0.24 \\
& R75p & $R_{\mathrm{d}}>48 \mathrm{~mm}$ & $-2.79^{* *}$ \\
& R95p & $R_{\mathrm{d}}>143 \mathrm{~mm}$ & $-1.70^{+}$ \\
& R95pTOT & $143 \mathrm{~mm}$ & $1.81^{+}$ \\
\hline Herceg Novi & SDII & $/$ & -0.49 \\
& R75p & $R_{\mathrm{d}}>23.4 \mathrm{~mm}$ & $-1.94^{+}$ \\
\hline & R95p & $R_{\mathrm{d}}>59.9 \mathrm{~mm}$ & -0.32 \\
& R95pTOT & $59.9 \mathrm{~mm}$ & 0.54 \\
\hline
\end{tabular}

** Significant at $1 \%$ level.

+ Significant at $10 \%$ level.

extreme precipitation events to the change in the total amount of precipitation (Klein Tank and Können, 2003). This is particularly important in areas that are at extreme risk of soil erosion. Number of dry days with precipitation less than $1 \mathrm{~mm}$ day $^{-1}$ has also been analysed.

The statistical significance of the calculated trends of the indices was tested using a Mann-Kendall test. This method has been applied because it is more suitable for non-parametric distributions. Mann-Kendall test is used for trend analysis in ETCCDI workshops (Zhang et al., 2005). Sen's (1968) slope estimator has been used for trend estimation of indices. This is a more robust approach for trend estimation of indices based on daily data.

A new and improved version of Objective Grosswetterlagen catalogue (James, 2007) is "SynopVis Grosswetterlagen" $(\mathrm{SVG})^{1}$. The SVG series circulation types for European

\footnotetext{
1 The SVG catalogue was kindly sent by the author himself P. M. James
}

Table 6. The linear trends for GWLs with the highest $E_{\mathrm{c}}$ for dry days in Crkvice and Herceg Novi.

\begin{tabular}{lllll}
\hline HM & WA & SA & SWA & NWA \\
\hline-0.015 & 0.037 & 0.085 & 0.050 & 0.044 \\
\hline
\end{tabular}

Table 7. The linear trends for GWLs with the highest Ec for R75p nad R95p indices in Crkvice and Herceg Novi.

\begin{tabular}{lllllll}
\hline TM & TB & HFZ & HNFZ & TRM & NEZ & SEZ \\
\hline-0.004 & 0.028 & -0.063 & -0.105 & -0.046 & -0.006 & -0.039 \\
\hline
\end{tabular}

land areas were used to explore the relationship between precipitation in Krivošije region and atmospheric circulation.

The SVG system is an objective computational version of the 29-type Hess and Brezowsky Grosswetterlagen (GWL) system of classifying European synoptic regimes (Table 3). The GWLs are defined according to the direction of movement air flow and frontal zones and anticyclonic and cyclonic features in relation to Central Europe. According to the direction of movement, air flow GWLs are grouped into ten supertypes (Grosswettertypen, GWT) (Table 3). The SVG method is based on MSLP, Z500 and Z500-Z1000-Thickness and uses the "20th Century Reanalysis" dataset from 1871 to 2008, extended to the present day with NCEP Reanalysis. The domain for the pattern correlations has been more tightly focussed on the European land areas and the 29 types have been optimized by separating them out more effectively in phase-space. The SVG series have the same meanings and nomenclature as the original types and are also filtered so that the minimum allowed event duration is three days (as in Hess and Brezowsky). Also, SVG system has "transitional days", denoted "Ue" (for Uebergangstag) - days with poor correspondence to any of the 29 types.

To analyse the relationship between extreme precipitation events and circulation types, we have used an efficiency coefficient $\left(E_{\mathrm{c}}\right)$. This coefficient presents ratio between a relative frequency of a given circulation type in extreme precipitation events to its mean frequency in the investigated period. If the efficiency coefficient is higher than 1.0, this means that the given circulation type tends to be condutive to extreme dry days and wet (R75p and R95p indices) precipitation events. A linear trend of frequency of circulation types was calculated for GWLs which have the highest value of Ec in Crkvice and Herceg Novi.

Cony et al. (2006) used the effectiveness coefficient in order to determine which Hess-Brezowsky Grosswetterlagen have occured more/less frequently during extreme cold events than others for 135 stations distributed around Europe. Also in their study, Kyselý and Huth (2008) use 


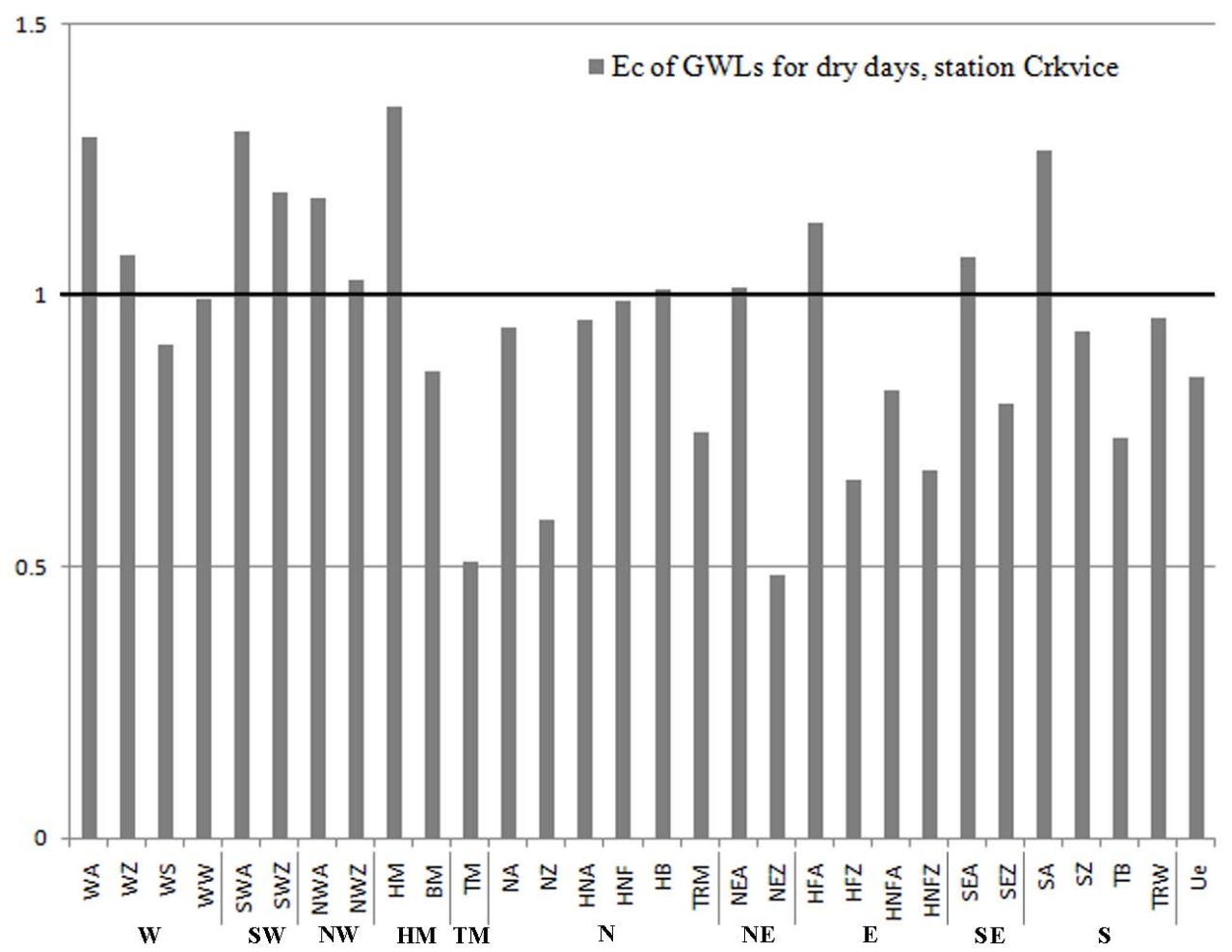

Fig. 6. The efficiency coefficient $\left(E_{\mathrm{c}}\right)$ of GWLs for dry days in station Crkvice, period 1951-2007.

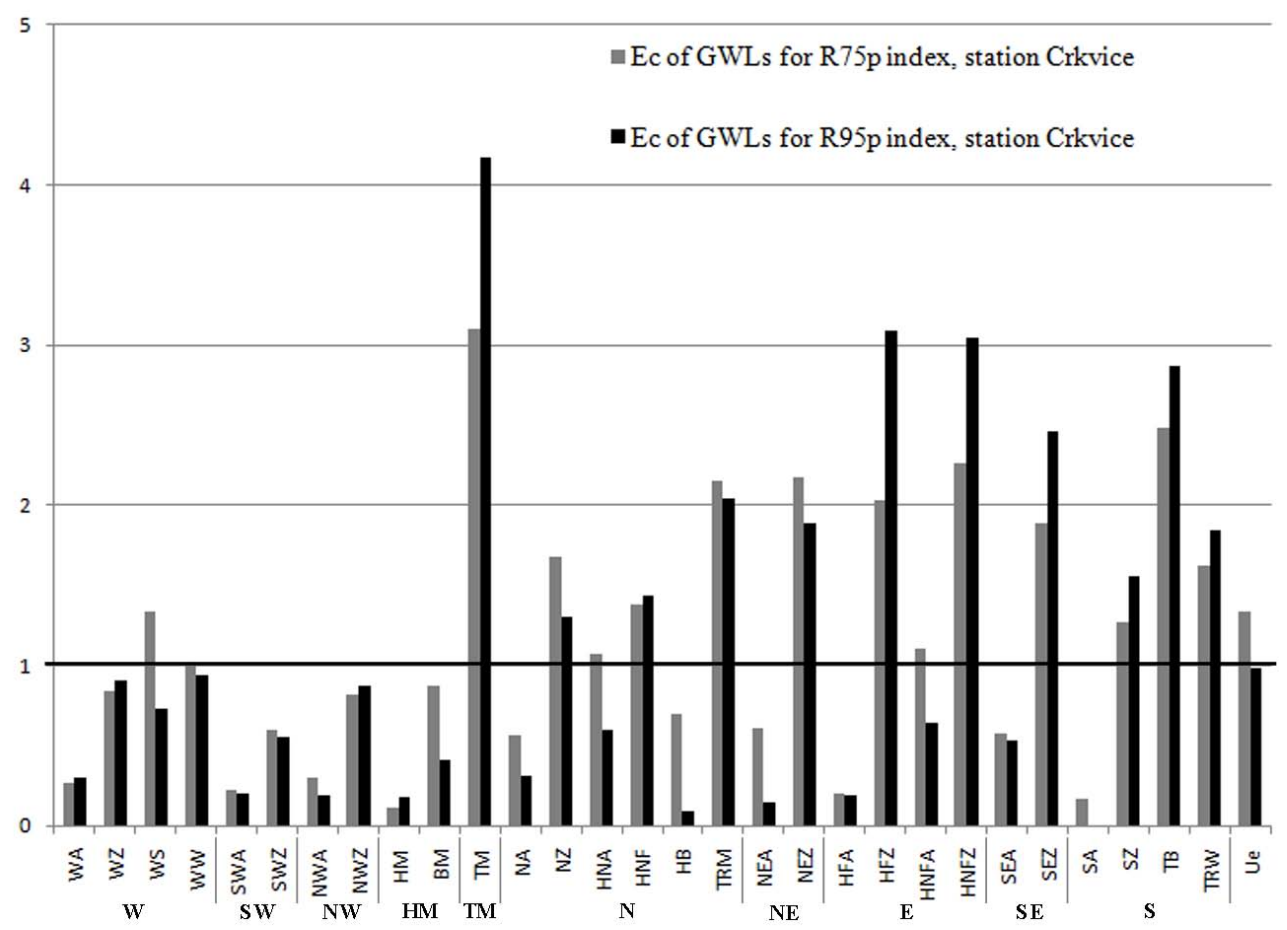

Fig. 7. The efficiency coefficient $\left(E_{\mathrm{c}}\right)$ of GWLs for R75p and R95 in station Crkvice, period 1951-2007. 


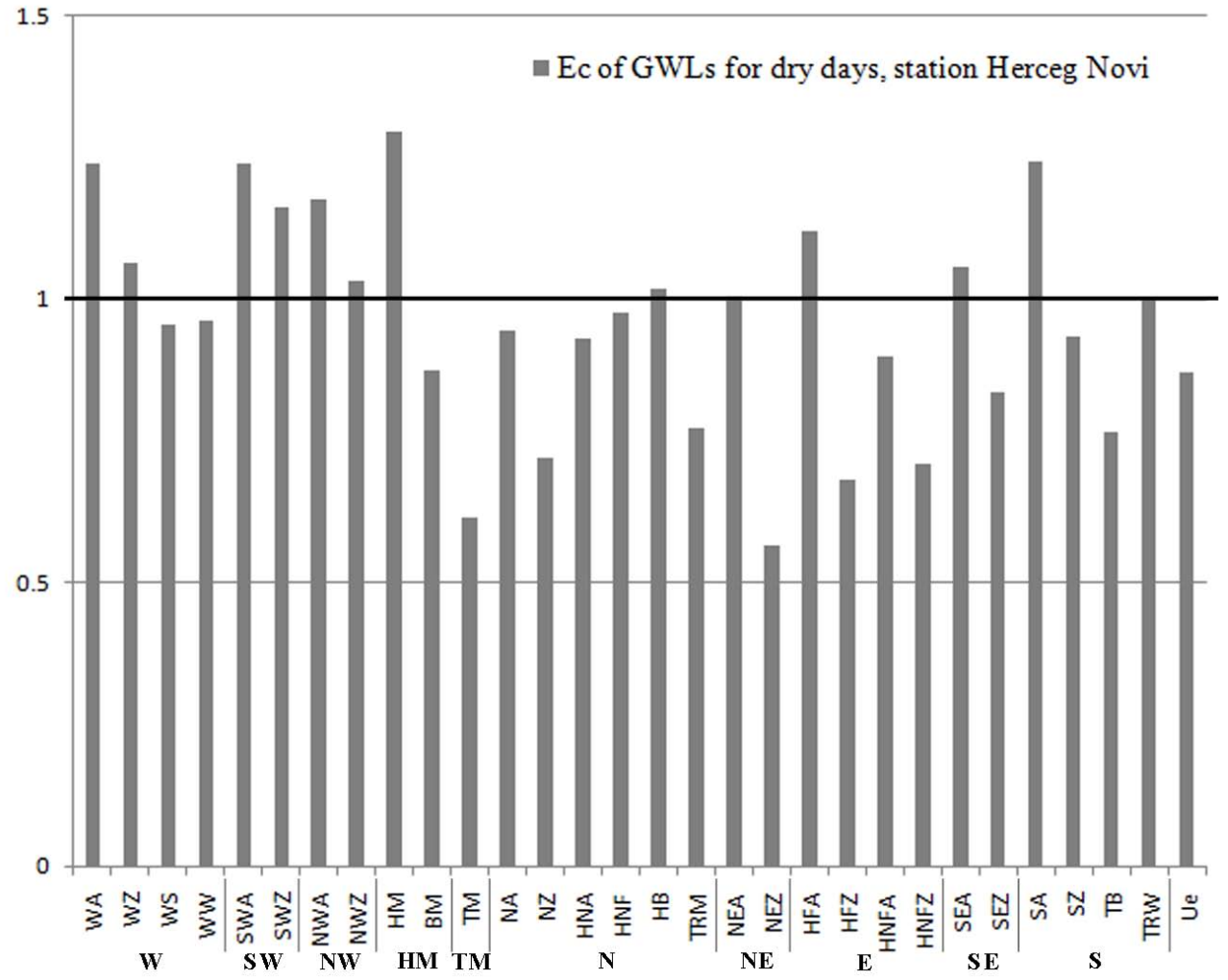

Fig. 8. The efficiency coefficient $\left(E_{\mathrm{c}}\right)$ of GWLs for dry days, station Herceg Novi, period 1951-2007.

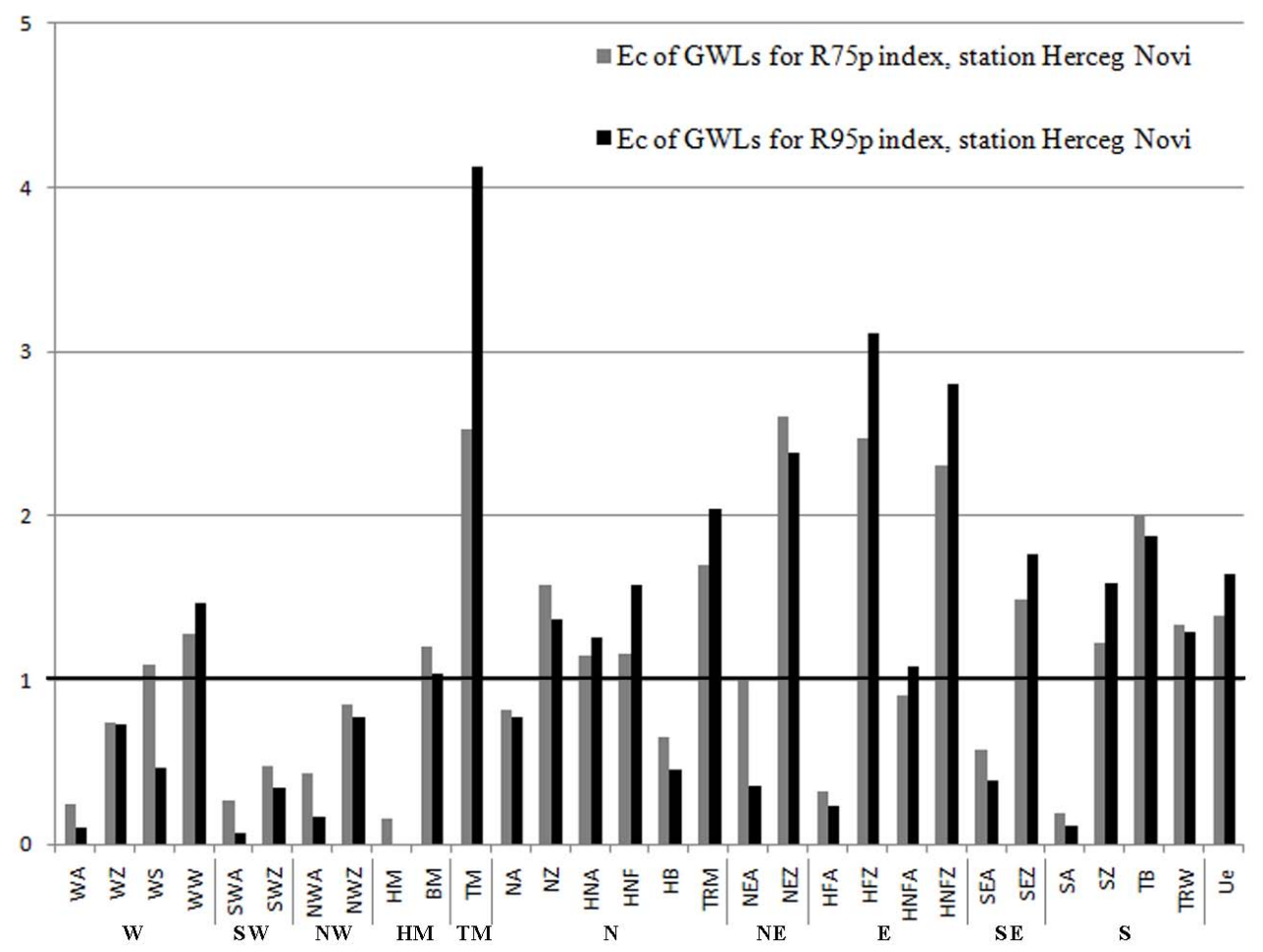

Fig. 9. The efficiency coefficient $\left(E_{\mathfrak{c}}\right)$ of GWLs for R75p and R95p in station Herceg Novi, period 1951-2007. 


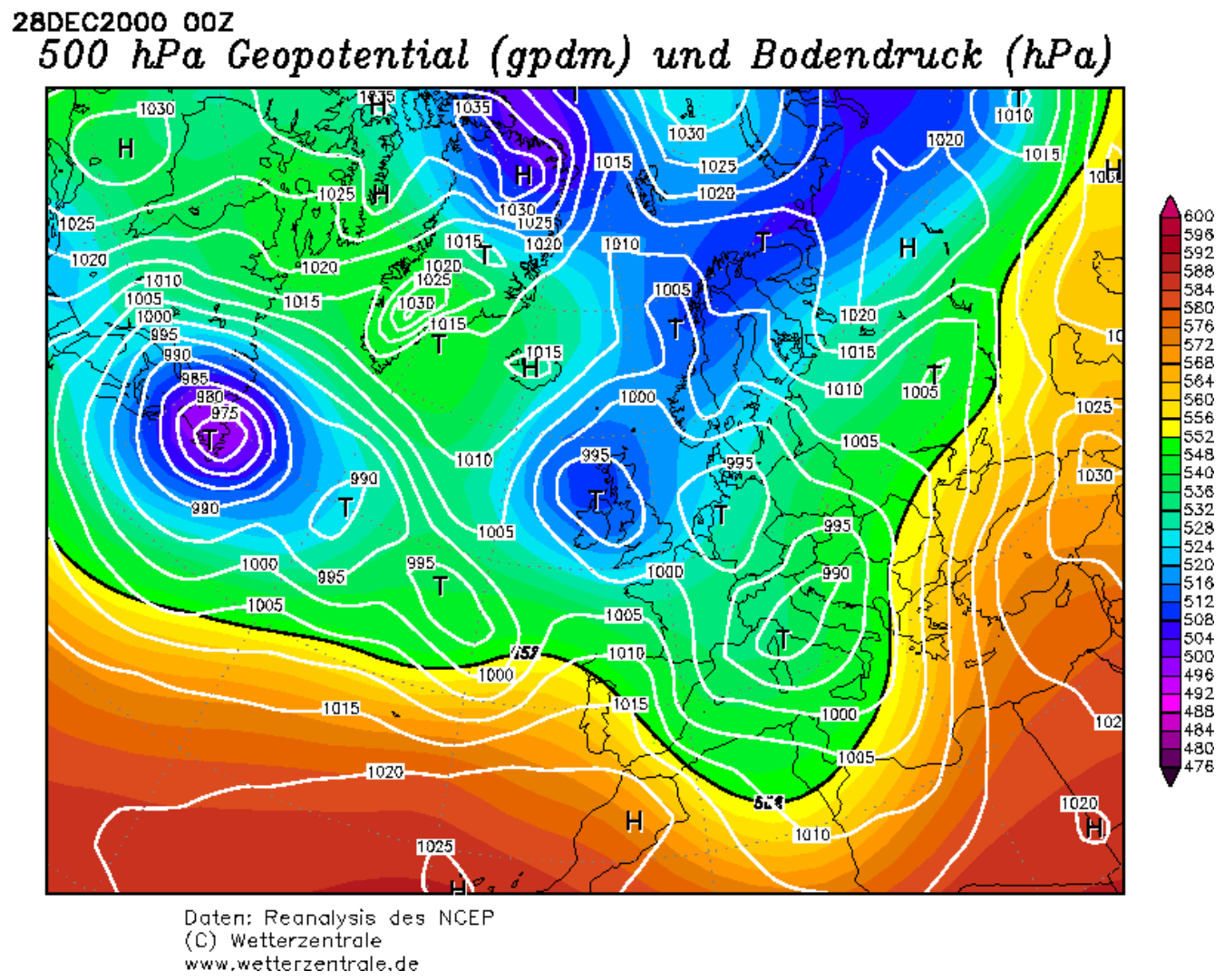

Fig. 10. Composite map of sea level pressure $(\mathrm{hPa})$ and $500 \mathrm{hPa}$ geopotential fields for the North Atlantic Ocean and Europe, 28 December 2000 (http://www.wetterzentrale.de/).

this coefficient for examining the relationship between HessBrezowsky circulation types which are condutive to summer heat waves at stations over most of Europe. Planchon et al. (2009) calculated precipitation amounts and percentages for objective GWL types and identified weather patterns causing heavy winter rainfall in Britanny (France).

\section{Results and discussion}

\subsection{Statistical analysis of extreme precipitation in the Krivošije region}

There is an incresing trend in number of dry days in Crkvice and Herceg Novi (Table 4), indicating that the number of dry days has incresed significantly ( $0.1 \%$ level of significance). An increse at both stations would reflect drier climate. This may have effects on vegetation and ecosystems (Peterson et al., 2001).

A simple measure of precipitation intensity (SDII) does not indicate much change over the $57 \mathrm{yr}$ period. A negative and nonsignificant trend was found at both stations.

It is also important to determine to what extent annual precipitation, decreases in the number of precipitation days and decreases in daily precipitation intensity could be explained by the changes in the number of wet and very wet days. Therefore, R75p and R95p were analysed.

There is statistically significant decrease in R75p (1\% level of significance) and R95p (10\% level of significance) for Crkvice (Table 5). Herceg Novi also shows significant decrease in R75p index (10\% level of significance). There is a decrease trend in R95p index but this change is nonsignificant.

Kostopoulou and Jones (2005) noticed contrasting trends of heavy rainfall events between an increase in the central Mediterranean (Italy) and a decrease over the Balkans.

The index R95pTOT is a measure of very extreme precipitation events. It should show whether the obtained results are in agreement with the amount of precipitation during wet days. This index shows an increasing statistically significant trend for Crkvice according to the Mann-Kendall test. The intensity of precipitation during very wet days increased at a rate of $1.8 \%$ annualy (Fig. 5). 


\subsection{Relationships between the indices of precipitation extremes in the Krivošije region and circulation types}

The effectiveness coefficient $\left(E_{\mathrm{c}}\right)$ of the circulation types was calculated in days with $R<1.0$ (dry days), wet (R75p) and very wet (R95p) days. The value of $E_{\mathrm{c}}$ coefficients higher than 1.0 show that certain circulation type is more frequent in these days, thus the Ec less than 1.0 shows that circulation type is less frequent in these events. Figures 6, 7, 8 and 9 show the obtained $E_{\mathrm{c}}$ using time series for stations Crkvice and Herceg Novi in the period 1951-2007.

The highest values of $E_{\mathrm{c}}$ for days with $R<1.0 \mathrm{~mm}$ in Crkvice were calculated for types HM, WA, SA, SWA, NWA (Fig. 6). During these types, area of high pressure is over South and Central Europe and depressions are over western parts of North Atlantic, West and North Europe. The frontal zones move from west towards the interior of the continent, while stable conditions are over Mediterranean. All of these have the anticyclonic features in relation to Central Europe. Also, they belong to westerly, south/southwesterly and northwesterly circulation. Most of these types show positive linear trend of frequency in period 1951-2007 (Table 6). The number of dry days $(R<1.0 \mathrm{~mm})$ also shows positive trend for Crkvice in the investigated period.

The GWLs which had occured more frequently during wet (R75p) and very wet (R95p) precipitation events in station Crkvice are TM, HFZ, HNFZ, TB, TRM, NEZ, SEZ (Fig. 7). These types show the cyclonic features in relation to Central Europe and belong to southerly, easterly and northerly circulation. For most of them are calculated negative linear trends for period 1951-2007 (Table 7). During these types there is an active Siberian high over North and East Europe and Azores high over the Atlantic. At the same time the lows move from North Atlantic toward Southwest and South Europe. There are depressions coming from the west over Biscay Bay and Garonne River moving towards Ligurian Sea. Under these conditions the impact of Icelandic depression is presented in the area of Krivošije.

Similar results of Ec are for station Herceg Novi (Figs. 8, 9). The westerly, southwesterly and northwesterly circulation types with the anticyclonic features are favourable for dry days and the northerly, easterly and southerly circulation types with cyclonic conditions over Central Europe are more frequent for days with heavy precipitation events.

In most cases, the results for Herceg Novi are in agreement with those obtained for Crkvice. Local factors such as morphology (in terms of steep slopes over the relatively small area of the Krivošije region) have a considerable impact on precipitation totals. In Krivošije region the most frequent are orographic and frontal type of rainfall. During the summer convectional type of rainfall occurs locally. Mediterranean area as source of moisture, rising air over the Orijen Mountain and very low dew point are the factors that led Krivošije region to be the wettest Mediterranean area.
The Mediterranean area is well known as a region of frequent cyclone formation. There are two main centres of maximum cyclone frequency: one is in the Gulf of Genoa and Southern Italy (the western Mediterranean centre) and the other is over the Aegean Sea and Cyprus (the eastern Mediterranean centre). In the Gulf of Genoa, the frequency of cyclones (especially of intense cyclones) is particularly high in winter (Maheras et al., 2001). The Adriatic Sea also appears to be an area of high-frequency cyclone occurrence (Radinović, 1987).

During the winter, anticyclones over eastern and northern Europe (Siberian anticyclone) and Genoa cyclones cause a depression that moves from the Adriatic Sea towards the southeast and east, and brings in humid weather conditions. This is the main reason why Crkvice and Herceg Novi have their maximum precipitation rates during the winter.

Brzović and Jurčec (1997) found that the majority of Adriatic cyclones do not show significant surface-pressure changes in their centres during their movement along the Adriatic. They suggested that the orographic influence that occurs in such a small area is of great importance for cyclone development and that cyclone development is too rapid to allow for a latent heat release to contribute significantly to cyclone intensification.

The cyclones generated over the Gulf of Genoa are important for annual precipitation as well as for extreme precipitation events. Therefore, a case study has been isolated and analysed for the day when the maximum daily precipitation was recorded in Crkvice for 1951-2007. The analysis for the maximum single-day precipitation amount (recorded on 28 December 2000, at $452.5 \mathrm{~mm}$ ) shows strong activity Genoa cyclogenesis. On that day there was a prevailing Grosswetterlagen Cental European Low (GWL TM). This weather pattern shows the highest value of Ec for wet and very wet events. The HNZ type was preceded by this events. The analysis of composite sea-level pressure (hPa) and $500 \mathrm{hPa}$ geopotential fields (Fig. 10) shows synoptic conditions, during which the areas of low pressure and the direction of frontal zones were over the North Atlantic and Western and Central Europe towards the Mediterranean. Genoa cyclogenesis and frontal zones slowly moving eastwards have caused humid and unstable air mass from southsouthwestern direction bringing heavy precipitation at the slopes of Orijen Mountain.

\section{Conclusions}

The analysis presented here revealed relationships between indices of precipitation extreme and circulation types in the Krivošije region during the period of 1951-2007. Number of dry days, including R75p, R95p and R95pTOT indices, showed statistically significant trends for Crkvice, as did the number of dry days and R75p index for Herceg Novi. The results for Crkvice suggest that the number of days with 
precipitation significantly decreased. For Herceg Novi, the amount of precipitation due to dry days decreased as well.

Regarding relation to atmospheric circulation, westerly, southwesterly and northwesterly circulation types with anticyclonic features are more frequent for dry days, and northerly, easterly and southerly types for wet and very wet days (R75p and R95p indices). Also, the types with cyclonic conditions over central Europe show a large proportion of R75p and R95p.

Krichak and Alpert (2005) suggested that the precipitation decline over the western part of the Mediterranean over the last several decades of the 20th century has been linked to the positive trend in the North Atlantic Oscillation (NAO). At the same time, the precipitation decline over the eastern region of the Mediterranean may be explained by the positive trend in the East Atlantic Western Russia (EAWR) pattern. Investigating the relationship between the NAO index and precipitation variability in Serbia during the period 1951-2000, Ducić et al. (2006) also noticed the impact of NAO for stations in the southeastern part of the country.

Kostopoulou and Jones (2007a) found that during the winter season, large scale features situated in Northern Europe affect atmospheric circulation over the eastern part of the Mediterranean, whereas the Atlantic (Azores) anticyclone and the Asian Thermal Low define atmospheric circulation in the summer.

Orographic influence over the small investigated area of Montenegro is of the greatest importance for the high precipitation amounts recorded in the Krivošije region (Crkvice).

Considering the fact that the Mediterranean is characterised by very low precipitation totals during the summer, future work should consider the seasonal scale of the indices of precipitation extremes, especially for the winter season or the period from October to April. In addition, it could be of interest to investigate the relationships between extreme indices and circulation types in other parts of the Mediterranean region.

Acknowledgements. This study was supported by the Serbian Ministry of Education and Science, under Grants III 47007 and III 43007.

Edited by: F. Guzzetti

Reviewed by: M. Brunet-India and two other anonymous referees

\section{References}

Alpert, P., Ben-Gai, T., Baharad, A., Benjamini, Y., Yekutieli, D., Colacino, M., Diodato, L., Ramis, C., Homar, V., Romero, R., Michaelides, S., and Manes, A.: The paradoxical increase of Mediterranean extreme daily rainfall in spite of decrease in total values, Geophys. Res. Lett., 29, 1536, doi:10.1029/2001GL013554, 2002.

Brunet, M., Sigró, J., Jones, P. D., Saladié, O., Aguilar, E., Moberg, A., Lister, D., and Walther, A.: Long-term changes in extreme temperatures and precipitation in Spain, Contribution to Science, 3, 331-342, 2007.

Brzović, N. and Jurčec, V.: Numerical simulation of the Adriatic cyclone development, Geofizika, 14, 29-46, 1997.

Caesar, J., Alexander, L. V., Trewin, B., Tse-ring, K., Sorany, L., Vuniyayawa, V., Keosavang, N., Shimana, A., Htay, M. M., Karmacharya, J., Jayasinghearachchi, D. A., Sakkamart, J., Soares, E., Hung, L. T., Thuong, L. T., Hue, C. T., Dung, N. T. T., Hung, P. V., Cuong, H. D., Cuong, N. M., and Sirabaha S.: Changes in temperature and precipitation extremes over the Indo-Pacific region from 1971 to 2005, Int. J. Climatol., 31, 791-801, 2011.

Cony, M., Hernandez, E., and Del Teso, T.: Influences of synoptic scale in generation of extremly cold days in Europe, Atmosera, 21, 389-401, 2008.

Costa, A. C. and Soares, A.: Homogenization of Climate Data: Review and New Perspectives Using Geostatistics, Math. Geosci., 41, 291-305, doi:10.1007/s11004-008-9203-3, 2009.

Gerstengarbe, F. W. and Werner, P.: Katalog der Grosswetterlagen Europes (1881-2004), PIK Report nr.100, Postdam-Institut für Klimafolgenforschung, 153 pp., 2005.

Ducić, V., Milovanović, B., and Luković, J.: Connection between ENSO index, NAO index and decadal-scale variability of precipitation in Serbia, in: Proceedings of the Third International Conference- Global changes and regional challenges, Sofia, Bulgaria, 28-29 April 2006, 137-142, 2006.

Dunkeloh, A. and Jacobeit, J.: Circulation dynamics of Mediterranean precipitation variability 1948-98, Int. J. Climatol., 23, 1843-1866, 2003.

Durão, R., Pereira, M. J., Costa, A. C., Côrte-Real, J. M., and Soares, A.: Indices of precipitation extremes in Southern Portugal - a geostatistical approach, Nat. Hazards Earth Syst. Sci., 9, 241-250, doi:10.5194/nhess-9-241-2009, 2009.

Durão, R. M, Pereira, M. J., Costa, A. C., Delgado, J., del Barriod, G., and Soares, A.: Spatial-temporal dynamics of precipitation extremes in southern Portugal: a geostatistical assessment study, Int. J. Climatol., 30, 1526-1537, 2010.

González-Hidalgo, J.C., De Luis, M., Raventos, J., and Sanchez, J. R.: Spatial distribution of seasonal rainfall trends in a western Mediterranean area, Int. J. Climatol., 21,843-860, 2001.

Goodess, C. M. and Jones, P.D.: Links between circulation and changes in the characteristics of Iberian rainfall, Int. J. Climatol., 22, 1593-1615, 2002.

James, P. M.: An objective classification method for Hess and Brezowsky Grosswetterlagen over Europe, Theor. Appl. Climatol., 88, 11-42, 2007.

Kioutsioukis, I., Melas, D., and Zerefos, C.: Statistical assessment of changes in climate extremes over Greece (1955-2002), Int. J. Climatol., doi:10.1002/joc.2030, 2010.

Klein Tank, A. M. G., and Können, G. P.: Trends in Indices of Daily Temperature and Precipitation Extremes in Europe, 1946-99, J. Climate, 16, 3665, doi:10.1175/1520442(2003)016<3665:TIIODT>2.0.CO;2, 2003.

Kostopoulou, E. and Jones, P. D.: Comprehensive analysis of the climate variability in the eastern Mediterranean. Part I: map-pattern classification. Int. J. Climatol., 27, 1189-1214, doi:10.1002/joc.1467, 2007a.

Kostopoulou, E. and Jones, P. D.: Comprehensive analysis of the climate variability in the eastern Mediterranean. Part II: relationships between atmospheric circulation patterns and 
surface climatic elements, Int. J. Climatol., 27, 1351-1371, doi:10.1002/joc.1466, 2007b.

Krichak, O. S. and Alpert, P.: Signatures of the NAO in the atmospheric circulation during wet winter months over the Mediterranean region, Theo. Appl. Climatol., 000, 1-13, doi:10.1007/s00704-004-0119-7, 2005.

Kyselý, J. and Huth, R.: Relationships of surface air temperatures anomalies over Europe to persistence of atmospheric circulation patterns conductive to heat waves, Adv. Geosci., 14, 243-249, 2008

Maheras, P., Flocas, H. A., Patrikas, I., and Anagnostopoulou, C.: A 40 year objective climatology of surface cyclones in the Mediterranean region: Spatial and temporal distribution, Int. J. Climatol., 21, 109-130, 2001.

Moberg, A., and Jones, P. D.: Trends in indices for extremes in daily temperature and precipitation in Central and Western Europe, 1901-99, Int. J. Climatol., 25, 1149-1171, 2005.

Moberg, A., Jones, P. D., Lister, D., Walther, A., Brunet, M., Jacobeit, J., Alexander, L. V., Della-Marta, P. M., Luterbacher, J., Yiou, P., Chen, D., Klein Tank, A. M. G., Saladié, O., Sigró, J., Aguilar, E., Alexandersson, H., Almarza, C., Auer, I., Barriendos, M., Begert, M., Bergstrom, H., Bohm, R., Butler, C. J., Caesar, J., Drebs, A., Founda, D., Gestengarbe, F. W., Micela, G., Maugeri, M., Osterle, H., Pandzic, K., Petrakis, M., Srnec, L., Tolasz, R., Tuomenvirta, H., Werner, P. C., Linderholm, H., Philipp, A., Wanner, H., and Xoplaki, E.: Indices for daily temperature and precipitation extremes in Europe analysed for the period 1901-2000, J. Geophys. Res., 111, D22106, doi:10.1029/2006JD007103, 2006.

Osborn, T. J., Hulme, M., Jones, P. D., and Basnett, T. A.: Observed trends in the daily intensity of United Kingdom precipitation, Int. J. Climatol., 20, 347-364, 2000.

Peterson, T. C., Folland, C., Gruza, G., Hogg, W., Mokssit, A., and Plummer, N.: Report on the activities of the Working Group on Climate Change Detection and Related Rapporteurs 1998- 2001. World Meteorological Organisation Rep. WCDMP-47, WMOTD 1071, Geneva, Switzerland, 143 pp., 2001.

Planchon, O., Quénol, H., Dupont, N., and Corgne, S.: Application of the Hess-Brezowsky classification to the identification of weather patterns causing heavy winter rainfall in Brittany (France), Nat. Hazards Earth Syst. Sci., 9, 1161-1173, doi:10.5194/nhess-9-1161-2009, 2009.

Radinović, D.: Mediterranean Cyclones and their Influence on the Weather and Climate, Programme on Short and Medium Range Weather Prediction Research (PSMP), W.M.O Sofia 24, 1987.

Radovanović, M., Ducić, V., and Milovanović, B.: The climate of Orjen mountain. Advances in the studies of fauna of the Balkan Peninsula, Monograph, No 22, Institute for Nature Conservation of Serbia, Belgrade, 73-78, 2008.

Sen, P. K.: Estimates of the regression coefficient based on Kendall's tau. J. Amer. Statist. Assoc., 63, 1379-1389, 1968.

Sousa, P. M., Trigo, R. M., Aizpurua, P., Nieto, R., Gimeno, L., and Garcia-Herrera, R.: Trends and extremes of drought indices throughout the 20th century in the Mediterranean, Nat. Hazards Earth Syst. Sci., 11, 33-51, doi:10.5194/nhess-11-33-2011, 2011.
Szentimrey, T.: Statistical problems connected with the homogenization of climatic time series, edited by: Heino, R., Climate variations in Europe, Proceedings of the European workshop held in Kirkkonummi (Majvik), Finland, May 1994, Publications of the Academy of Finland, 330-339, 1994.

Szentimrey, T.: Multiple analysis of series for homogenization (MASH), in: Proceedings of the second seminar for homogenization of surface climatological data, Budapest, Hungary, WMOTD No. 962, WCDMP No. 41, 27-46, 1999.

Szentimrey, T.: Multiple analysis of series for homogenization (MASH); Verification procedure for homogenized time series, in: Fourth seminar for homogenization and quality control in climatological databases. Budapest, Hungary, WMO-TD No. 1236, WCDMP No. 56, 193-201, 2003.

Unkašević, M., Tošić, I., and Vujović, D.: Variability and probability of annual and extreme precipitation over Serbia and Montenegro, Theor. Appl. Climatol., 79, 103-109, doi:10.1007/s00704004-0060-9, 2004.

Tolika, K., Anagnostopoulou, C., Maheras, P., and Kutiel H.: Extreme precipitation related to circulation types for four case studies over the Eastern Mediterranean, Adv. Geosci., 12, 87-93, 2007 ,

http://www.adv-geosci.net/12/87/2007/.

Toreti, A., Xoplaki, E., Maraun, D., Kuglitsch, F. G., Wanner, H., and Luterbacher, J.: Characterisation of extreme winter precipitation in Mediterranean coastal sites and associated anomalous atmospheric circulation patterns, Nat. Hazards Earth Syst. Sci., 10, 1037-1050, doi:10.5194/nhess-10-1037-2010, 2010.

Tsonis, A., Swanson, K., and Kravtsov, S.: A new dynamical mechanism for major climate shifts, Geophys. Res. Lett., 34, L13705, doi:10.1029/2007GL030288, 2007.

Zhang, X., Vincent, L. A., Hogg, W. D., and Niitsoo, A.: Temperature and precipitation trends in Canada during the 20th century, Atmos. Ocean, 38, 395-429, 2000.

Zhang, X., Aguilar, E., Sensoy, S.,. Melkonyan, H., Tagiyeva, U., Ahmed, N., Kutaladze, N., Rahimzadeh, F., Taghipour, A., Hantosh, T. H, Albert, P., Semawi, M., Karam Ali, M., Halal Said Al-Shabibi, M., Al-Oulan, Z., Zatari, T., Al Dean Khelet, I., Hamoud, S., Sagir, R., Demircan, M., Eken, M., Adiguzel, M., Alexander, L., Peterson, T. C., and Wallis, T.: Trends in Middle East climate extreme indices from 1950 to 2003, J. Geophys. Res., 110, D22104, doi:10.1029/2005JD006181, 2005.

Zhang, X., Zwiers, F. W., and Hegerl, G: The influences of data precision on the calculation of temperature percentile indices, Int. J. Climatol., 29, 321-327, doi:10.1002/joc.1738, 2009.

Zolina, O., Simmer, C., Kapala, A., Bachner, S., Gulev, S., and Maechel, H.: Seasonally dependent changes of precipitation extremes over Germany since 1950 from a very dense observational network, J. Geophys. Res., 113, D06110, doi:10.1029/2007JD008393, 2008.

WMO: Technical Document 1125, World Meteorological Organization, GCOS-76, Geneva, Switzerland, 2002. 